\title{
Keskustelua tulevaisuuden koulusta ja hallinnasta
}

Esko Harni (2015): Kontrollikoulu. Näkökulmia koulutukselliseen hallintaan ja toisin oppimiseen. Jyväskylä: Kampus Kusannus. Jyväskylän yliopisto. 226 sivua. ISBN: 978-951-9113-96-8.

ESKO HARNI ON toimittanut teoksen kontrollikoulusta. Se tarjoaa kiinnostavia näkökulmia koulutukselliseen hallintaan ja koulujärjestelmän uudistamisen ja muutoksen pyrkimyksiin. Artikkelikokoelmissa hyvä ja kiinnostava teos syntyy ja vahvistuu silloin, kun yksittäiset artikkelien kirjoittajat saadaan tavalla tai toisella houkuteltua keskustelemaan myös keskenään. Tässä teoksessa näin ei ole tapahtunut. Kirjassa osa artikkeleista sitoutuu hallintateoreettiseen tutkimusperinteeseen ja osa lähinnä kriittiseen teoriaan ja kriittiseen pedagogiikkaan.

Kirjan juoni nousee nimensä mukaisesti ranskalaisen filosofin Gilles Deleuzen (1990) paljon siteeratusta hallintateoreettisesta esseestä. Sen oleellinen idea on siirtyminen kurittavasta kuriyhteiskunnasta kohti vaikeammin tunnistettavaa ja kaikkialle tunkeutuvaa hallinnollisuutta, joka pyrkii myös yksilöiden sisäisen mielenmaailman syvälliseen kontrollointiin. Kirja soveltaa Deleuzeesseen perusideaa koulukontekstiin hahmotellen samalla esiin koulutusjärjestelmän tehtävää.

KIRJA JAKAUTUU kolmeen osaan, joista ensimmäinen johdattaa, kylläkin hieman ontuvasti, tematiikkaan kahdella avausartik- kelillaan. Epilogiin on pyydetty avainartikkeli molempien koulukuntien edustajilta: kriittisen teorian ja kriittisen pedagogiikan lähtökohdista Olli-Pekka Moisiolta ja Matti Rautiaiselta sekä hallinnanteoreettisen keskusteluperinteen edustajalta, Jussi Vähämäeltä.

Moision ja Rautiaisen artikkelin suhde kirjan kontrollikoulun ydinajatukseen jää kuitenkin epäselväksi.

Artikkelissa argumentoidaan ihan kiinnostavasti ja hieman historiallisestikin taustoittaen koulutusjärjestelmän tilaa. Koulu tosin leimataan kovin muuttumattomaksi, liian tietopainotteiseksi ja opettajavaltaiseksi järjestelmäksi, joka laiminlyö oppilaiden demokratia- ja tunnekasvatuksen. Opettajien toivotaan siirtyvän opettajavaltaisuudesta oppilaiden itsenäisen opiskeluprosessien mahdollistajiksi. Opettajat kykenisivät akateemisen intellektuellin roolissa ohjaamaan paremmin oppilaiden itsenäisiä opiskeluprosesseja ja vastustamaan sosiaalisen median ja verkkoympäristöjen tyhmistäviä vaikutuksia. Artikkelissa varoitellaan myös koulutusjärjestelmän "kalvinisoitumisen" ja epätasa-arvoistumisen vaaroista, mikä voi johtaa koulun vain huippuja treenaavaksi instituutioksi. On kuitenkin vaikea ymmärtää, miten artikkeli liittyy kirjan hallintateoreettisen kontrollikoulun ideaan. Pelkistyvätkö koulun valtasuhteet kriittisen pedaogiikan lähestymistavassa tosiaankin pelkästään opettaja-oppilassuhteen epätasa-arvoisuuden kritiikiksi?

TOISEN EPILOGIARTIKKELIN kirjoittaja Jussi Vähämäki muun muassa Deleuzen esseen ja kirjan kääntäjänä ja hallintateoreettisen tutkimusperinteen keskeisenä vaikuttajana on luonnollisesti kirjan kokonaisidean ytimessä. Välimäen artikkeli onkin tuttuun tapaan tulvillaan omaperäisten ideoiden ilotulitusta. Kontrolliyhteiskunnan uuden sukupolven edustajat joutuvat Vähämäen mukaan kehittelemään kokonaan uudenlaisia aseita ja vastarinnan muotoja, jos he haluavat vastustaa yhä syvemmälle ulottuvaa ja näkymätöntä persoonansa ohjailua ja hallinnointia. Kontrolliyhteiskunnassa ja tulevaisuuden koulussa suorastaan pakotetaan jatkuvaan itsensä ilmaisuun ja itsensä luovaan ja vapaaseen itsetoteutukseen. Näissä olosuhteissa vastarintaisten on vaikea puolustaa vapauttaan tässä vapauden illuusion ilmapiirissä, jossa yksilöt kuitenkin ovat täysin kontrolloituja.

Vähämäki heittää esiin muutaman villin ajatuksen vastarinnan 
muodoista ja uudenlaisesta luokkataistelusta, jonka ydin voisi olla vaikka "läskiksi heittäytyminen", jolla hän tarkoittaa esimerkiksi kieltäytymistä jatkuvasta kehittämisestä ja oman persoonansa pynttäämisestä myyntikuntoon. Vähämäki ehdottaa myös hiljaisuuden aukkojen ja tyhjiöiden luomista vastarinnan tiloiksi, Hiljaisuuksilla ja tyhjiöillä voisi rikkoa ehkä tehokkaimmalla tavalla kontrolliyhteiskunnan vallan ja hallinnan pyrkimyksiä. Teknotieteiden ja uudenlaisen koulutuksen myötä ihmisestä muokataan suorastaan eräänlaista ihmiskonetta. Subjekti on täten vaarassa menettää omaehtoista toimijuuttaan. Kontrolliyhteiskunnan olosuhteissa toisen halusta tulee "lacanilaisittain" omaa halua ja yksilö oppii opetetuksi, voimaantuu voimattomaksi ja (palkka)työstä tulee hänelle nautintoa ja nautinnosta (palkka)työtä.

Vähämäen heittoihin uudesta tulevaisuuden "yhteisestä, julkisesta ja julkeasta vapaasta koulusta" kannattaa tutustua. Sen verran herkullisella tavalla rienaavia näkökulmia hän tekstissään esittää. Tässä kirjakokokonaisuudessa Vähämäen epilogiartikkeli rakentaa oman iloittelevan kokonaisuutensa, vaikka se kommunikoin tietenkin hyvin myös kirjan ydinidean kanssa.

KIRJAN TOINEN luku avaa näkökulmia koulutukselliseen hallintaan sisältäen Heikki Silvennoisen ja Heikki Kinnarin kaksi yhteisartikkelia koulutuksesta, kilpailukyvystä ja hallinnasta sekä elinikäisestä oppimisesta hallinnan teknologiana. Silvennoinen ja Kinnari avaavat jo tuttuun tapaansa elinikäisen oppimisen hallinnan teknologiaa genealogisella lukutavallaan. He keskustelevat väestön hallinnan ongelmista ja koulutuksen moraalisesta säätelystä kohti talouskasvua palvelevaa hallintaa. Uudenlaisen ihmistyypin ja ihmisihanteen tuottamisen tarpeet synnyttävät myös uudenlaista moraalikoodistoa ja todellisuuskäsityksiä, joita muokataan muodollisen koulutuksen lisäksi erityisesti elinikäisen oppimisen laaja-alaisissa käytännöissä.

Kirjoittajien työikäisen aktiiviväestön muokkaamisen näkökulmat laajentavat kirjan näkökulmaa koulutusjärjestelmäkeskeisyydestä toisten mahdollisuuksien aikuiskoulutuksen ja kehittämisen kenttiin, joilla muokataan yhteiskuntaan ja talouteen kulloinkin sopivaa kunnon kansalaisuutta.

Esko Harni hahmottelee kakkosluvussa tulevaisuuden koulun tilaratkaisuja erilaisten koulua koskevien kehittämishankkeiden raportteja referoiden. Ratkaisuilla tavoitellaan siirtymää tehtaan ja vankilan kaltaisista laitoskouluista kohti virtaavaa tilaa ja läpinäkyvyyden kulttuuria, jossa oletetaan luovuuden, leikin ja innovaatioiden kukoistavan. Tällaisista tulevaisuuden koulun visiokuvista tehtaillaan Suomelle uudenlaista vientituotetta, joka näyttävyydessään voisi kiinnostaa ostajia koulutuksen markkinoilla. Perusideana on siirtyä eristämisen tiloista liikkeen ja kommunikaation en- nalta arvaamattomiin ja satunnaiset kohtaamiset mahdollistaviin toiminnan ja liikkeen tiloihin ja "opiskelupesiin".

Tämän tyyppisillä koulun uusilla järjestysehdotuksilla pohjustetaan uuden työn ja talouden aktiivisen, luovan ja oma-aloitteisen oppijasubjektin kehkeyttämistä. Samalla murretaan koulutusjärjestelemän erillisyyttä yhdistämällä mukaan työn ja elinikäisen oppimisen tiloja samoihin oppimiskeskuksiin. Työelämästä jo tutut avokonttorit kahviautomaatin ympärille muodostuvine kohtaamistiloineen tulevat pakostakin mieleen artikkelia lukiessa. Työelämän työntekijöiden arkea rasittavat kehittämismuodit näyttävät siis rantautuvan ainakin ideatasolla myös koulumaailmaan. Kuvio kertoo hyvin konkreettisesti siitä, miten koulutuksen autonomista ja rauhoitettua tilaa pyritään murtamaan myös uusilla tilaratkaisuilla.

KAKKOSLUVUN VIIMEISESSÄ artikkelissa Heidi Elmgren nostaa kiinnostavalla tavalla esiin "heikkousalueilla” opettelun tärkeyden ihmisen kasvulle ja kehitykselle. Hän käyttää hyväkseen erityisesti Giorgio Agamben filosofista ajattelua. Elmgren leikittelee ja avaa käsitteitä, joita viime vuosien koulu-ja oppimiskeskusteluissa on kyllästykseen asti toisteltu. Hän purkaa vallitsevaa retoriikkaa oppimaan oppimisesta ja vahvuusalueilla työskentelystä, ja nostaa esiin Agambea hyödyntäen Aristoteleen ajatuksen hyödyntämättömien potentiaalien 
tärkeydestä eräänlaisena impotentiaalisuutena, joka ei aktualisoidu, ja säilyttää täten potentiaalisuutensa.

Aktiivinen kyky ei-tekemiseen ja ei-olemiseen tarkoittaa sitä, että impotentiaalisuuden aikana voi esimerkiksi levätä, lukea ja rikastaa henkisesti itseään. Opiskellessa on luvallista olla keskeneräinen, kun taas oppimaan oppiminen pitää sisällään jatkuvan aktualisoimisen ja tuottamisen vaatimuksen.

Kirjan kolmannessa luvussa siirrytään kriittisen teorian ja kriittisen pedagogiikan taustoittamaan keskusteluun toisin oppimisen pyrkimyksistä ja kehittämishankkeista. Lauri Lahikainen rakentaa inhimillisen pääoman teorian lähtökohdista kriittistä näkemystä, joka pyrkii ottamaan huomioon myös työelämän alistavissa käytännössä tapahtuneita muutoksia, jotka kirjoittajan mukaan tekevät Giroux'n ja McLarenin 20 vuotta vanhat analyysit jo kovin vanhanaikaisen oloisiksi.

Lahikainen tarkastelee yliopistoja ja koulua tuotannollisena yrityksenä, eikä pelkästään "ideologisena valtakoneistona". Lahikainen on kiinnostunut avaamaan inhimillisen pääoman teorian kokemuksellista ulottuvuutta, joka kilpailuasetelmista johtuen vaikeuttaa kollektiivista toimintaa ja voi johtaa minuuden tavaramuotoistumiseen. Myös Antti Paakkarin artikkelissa elää eräänlainen kriittisen pedagogiikan päivittämisen pyrkimys kontrolliyhteiskunnan aikaan, jossa valta- ja alistussuhteet piiloutuvat ja osuvaa kritiikkiä on yhä vaikeampi esittää.

Paakkarin tavoitteena on osoittaa, että kriittisellä pedagogiikalla ja Paulo Freiren valtaistamisen pedagogiikalla on edelleen annettavaa myös yhteiskunnassa, jossa itsensä toteuttamisesta on tullut jo suorastaan pakko ja kaikkinainen aktiivisuus ohjataan sisäisen yrittäjyyden kaapuun ja taloudellisten arvojen tuottamiseen. Kirjoittaja hakee uusia ajattelun eväitä uusmaterialismista, joka diskurssien sijasta kohdistaa päähuomionsa aineelliseen maailmaan ja toimijuuden ehtoihin sen sisällä. Näkökulma aineelliseen maailmaan virittyy teknologian uudenlaisesta suhteesta luokkahuoneessa. Tietotekniikka avaa Paakkarin mukaan kamppailun mutta myös toivon ja mahdollisten toisin olemisen ja tekemisen tiloja kontrolliyhteiskunnankin olosuhteissa.

Myös Juha Suoranta uskoo tietotekniikkaan ja rakentaa muodolliselle koulutusjärjestelmälle vaihtoehtoisia yhdessä tekemisen ja yhdessä oppimisen tiloja, joissa mahdollistuisi "vapautuminen itsekseen". Suoranta kehottaa keskittymään miten- kysymyksiin, joiden avulla voitaisiin kehittää kriittisen pedagogiikan innoittamana toisenlaisia oppimisprosesseja, jotka perustuvat vertaisoppimiselle. Näin rakennetaan itseymmärrystä ja yhteisvastuuta, joka kehittää vaihtoehtoisia ja yhteistoiminnallisia opiskelukäytäntöjä lamaannuttavan ja passivoivan nykykoulutusjärjestelmän tilalle.
Yliopisto hahmottuu Suorannan artikkelissa kovin kielteisin sävyin, kun hän toivoo yliopistoopiskelijoiden oppivan kritisoimaan "yliopistojen ällöttävän itseriittoista mahtipontisuutta ja järkälemäistä omahyväistä pysähtyneisyyttä". Wikipedioiden ja wikiopistojen avulla rakennetaan uudenlaisia toisintoimimisen käytäntöjä ja toimitaan solidaarisemman ja yhdenvertaisuutta ruokkivan yhteiskunnan puolesta ja samalla kyseenalaistetaan koko koulutusjärjestelmän oikeutusta.

Myös Tiina Nikkolan ja Esko Harnin artikkelissa kyseenalaistetaan perinteistä opettajakoulutusta ja rakennetaan uutta vertaisoppimisen idean varaan. He esittelevät opettajakoulutuksen integraatiokokeilua, jonka aikana tuleville opettajille rakennettiin "henkisesti avointa ja tyhjää tilaa". Näin kehiteltiin vaihtoehtoista opettajakoulutusta perinteisen fordistisen rationaliteetin mukaisesti toimiville tehdaskouluille.

KIRJA OLISI suuresti hyötynyt siitä, että artikkeleissa käytettyjä hallinnan tutkimuksen ja kriittisen pedagogiikan teoriasuuntausten keskeisisiä teoreettisia eroja ja ristiriitoja olisi avoimesti käsitelty, tunnistettu ja analysoitu heti kirjan epilogiartikkeleista liikkeelle lähtien. Nyt kirja jäi eräänlaiseksi hajanaiseksi synteesin yritykseksi, joka ei kuitenkaan taustoittanut erilaisten teoriakehysten ja lähestymistapojen välisiä ristiriitoja, erilaisia suhteita ja sidoksia valtaan ja alistukseen sekä käytäntöjen kehittämiseen ja tutkimukseen. 
Kriittisen teorian ja kriittisen pedagogiikan edustajat tekevät kärjistetysti ilmaisten eräänlaista vallankumousta koulutusjärjestelmän sisäisten auktoriteetti- ja valtasuhteiden murtamiseksi. $\mathrm{He}$ uskovat oppilaiden ja opiskelijoiden vertaisvalmennuksen kannattelevan nykyistä koulutus-ja sivistysjärjestelmää parempaan lopputulokseen kuin mitä opettaja-ja tietokeskeisellä nykyjärjestelmällä. Kriittisen pedagogiikan edustajat kamppailevat hankkeissaan hyvin toiminnallisella tavalla ja konkreettisten miten-kysymysten virittäminä paremman huomisen puolesta. Ehkä heidän kannattaisi viimeistään nyt paneutua myös miksi-kysymyksiin uudestaan.

Hallintateoreettisen teoretisoinnin edustajat toimivat ensisijaisesti tutkijoina, jotka pyrkivät omalla työllään ymmärtämään uudenlaisia hallinnoinnin ja syvenevän alistuksen käytäntöjä. Hallintateoreettisen koulukunnan edustajat ovat enemmän kiinnostuneita teoreettisessa mielessä ja aikalaisanalyyttisesti koulutuksen ja koulun muuttuvista tehtävistä ja rooleista. Kirjassa yhteen saatetuilla eri koulukuntien edustajilla näyttää olevan hyvin erilaisia peruslähtökohtia tietoon, tutkimukseen ja teoria-käytäntö-suhteisiin. Molemmat teoriasuuntaukset ovat herättäneet kasvatustieteissä voimakasta kiinnostusta, joten tutkimuksellisesti olisi ollut tärkeää ja tarpeellista pohtia ja jäsentää lähestymistapojen keskinäistä suhdetta hieman tarkemmin.

Teoreettisten erojen tunnistamisen ja analyysin sijasta kirja käynnistyy kuitenkin samanlaisuuksista. Yhdistäväksi perustaksi kirjan kokonaisuudelle riittää toteamus, jonka mukaan kaikki kirjoittajat ovat kiinnostuneita koulun ja koulutuksen yhteiskunnallisesta luonteesta. Samoin he ovat ainakin jossain määrin kriittisessä suhteessa vallitsevaa koulutusjärjestelmää ja koulua kohtaan. Suhteellisen yksimielisiä ollaan myös koulutuksen ja koulun muutostarpeista ja niiden syistä. Muutostarpeita kirjassa haetaan yhteiskunnallisista ja sosiaalisista ongelmista ja uuden työn ja talouden tarpeista, joiden ratkaisemiseen ja hallintaan tarvitaan ehkä myös uudenlaista koulua. Kirja siis argumentoi vahvasti koulutuksen ja koulutusjärjestelmän muutoksen puolesta.

Kirjan toimittaja kertoo johdannossa kirjalla olevan kaksiosainen luonne. Toiset artikkelit avaavat koulutukseen liittyviä hallinnallisuuteen ja valtaan liittyviä kysymyksiä. Toiset kertovat koulutusjärjestelmän muutoskokeiluista. Hallinnanteoreettiset artikkelit muodostavat ikään kuin kirjan teoreettisen kehyksen ja ytimen, ja kriittisen teorian ja pedagogiikan edustajat keskittyvät enemmänkin uuden koulu- ja oppimiskokeiluihin ja miten-kysymyksiin.

\section{OLISI OLLUT KIINNOSTAVAA} keskustella siitä, missä määrin kontrolliyhteiskunnan syvenevän hallinnan käytännöt hyödyntävät kouluissa ehkä hyvinkin tietoisesti myös kriittisen pedagogiikan toiminnallisten hankkeiden tuottamia valtaistavan vapauden illuusioita. Olisi ollut tärkeää ja myös kiinnostavaa kuulla, millaiset vastarinnan muodot ovat kriittisen teorian edustajien mielestä kontrollikoulun syvenevän hallinnollisuuden olosuhteissa mahdollisia.

Aiemmissa omissa tutkimuksissani (ks. esim. Filander 2003; 2007) olen kiinnittänyt huomiota siihen, miten myös liiketoimintajohtamisen ja yrittäjyyden empowerment-puheissa hyödynnetään hyvin saman tyyppisiä perusteluja ja jopa samaa retoriikkaa kuin kriittisen teorian ja kriittisen pedagogiikan ja vaihtoehtopedagogiikan lähestymistavoissa. Kaikki tavoittelevat itsensä altistamista ja itsensä ylittämistä, mikä samalla johtaa suurempaan tuottavuuteen. Tavoitteena on innostaa kaikkia työntekijöitä ja kehittäjien koko persoonallisuudellaan yrittäjyyden ja kehittäjyyden ilosanomaan, jonka avulla saadaan toimijat antamaan työlleen ihan kaikkensa ja työpaikan tuottavuus jatkuvaan nousuun. (ks. esim. Filander 2003, 41-45; Filander 2007; 160-161).

Jäin kovasti kaipaamaan kriittisen pedagogiikan edustajilta suurempaa itsereflektiivisyyttä hankekuvauksissaan, joiden voi väittää myös edustavan kontrolliyhteiskunnan syvenevän hallinnan ja alistamisen käytäntöjä. Lähimmäs tämän tyyppistä reflektiivisyyttä yltää Lahikainen, joka toteaa artikkelissaan, että "erilaisiin oppimismenetelmiin ei välttämättä ole mitään sisäänrakennettua mekanismia, joka estäisi niiden tava- 
ramuotoistumisen" (Lahikainen 2015, 168).

Kirjan alussa esitetään joukko hyviä kysymyksiä, kuten miksi talouspolitiikka ja esimerkiksi kilpailukyvyn diskurssi on iskostunut niin vahvasti puheeseen koulusta ja koulutuksesta? Onko koululla muuta tehtävää kuin vastata sille ulkoapäin asetettuihin vaatimuksiin? Erityisesti jälkimmäiseen kysymykseen kirja ei tuota kunnon vastauksia.

Kirjassa on hieman artikkelikokoelmille tyypillistä epätasaisuutta ja sen toimittamisprosessi olisi hyötynyt vielä ainakin yhdestä tarkastuskierroksesta. Ko- konaisuudesta löytyy myös artikkeleita, joiden ydinsanoma on jo muissa yhteyksissä moneen kertaan kerrottua. Toisaalta kirjasta löytyy kuitenkin myös tuoreita helmiä, jotka avaavat lukijassa uudenlaista ajattelua ja tarjoavat palkitsevia kokemuksia. Myös lukijat, jotka varsinaisesti eivät ole kiinnostuneita koulukeskusteluista, voivat hyötyä artikkelikoosteesta. Synteesiä kirjan kokonaisuudesta on vaikeaa rakentaa, mutta kärsivällinen lukija saa kyllä palkintonsa.

Karin Filander

FT, dosentti

Tampereen yliopisto

\section{LÄHTEET}

Deleuze G. (1990). Jälkikirjoitus kontrolliyhteiskuntiin. Kääntänyt: Jussi Vähämäki. ks. http://megafoni. kulma.net/index. php?art=184.

Filander, K. (2003). Vocabularies of Change - Analysing Talk on Change and Agency in Developmental

Work. Roskilde: Roskilde University Press.

Filander, K. (2007). Aikuisuus, sosiaalipedagogiikka ja uusi moraalijärjestys. Sosiaalipedagoginen aikakauskirja, 10-vuotisjuhlajulkaisu. Kuopio: Suomen sosiaalipedagoginen seura ry. $151-165$. 